\title{
Identifikasi Jamur pada Beberapa Bumbu Dapur Secara Makroskopis dan Mikroskopis
}

\author{
Ni Putu Rima Paramita \\ rimaparamita16@gmail.com \\ Program Studi Farmasi, Fakultas MIPA, Universitas Udayana
}

\begin{abstract}
ABSTRAK
Jamur merupakan organisme eukariotik yang mempunyai spora, berinti, tidak berklorofil, dan berbentuk seperti benang dengan dinding sel yang tersusun oleh selulosa dan kitin. Jamur merupakan mikroorganisme heterotrof yang bersifat saprofit atau parasit. Jamur memiliki struktur sel yang berbentuk bola atau filamen disebut hifa. Hifa dibedakan atas dua yaitu hifa fertile yang membentuk sel reproduktif dan tumbuh ke atas sebagai hifa udara serta hifa vegetatif yaitu hifa yang mencari makanan pada substratnya. Pada kondisi tertentu, sifat jamur dapat berubah menjadi patogen dan menyebabkan berbagai penyakit. Beberapa jamur yang mencemari bumbu dapur memiliki kemampuan dalam memproduksi racun atau toxin yang dapat menimbulkan penyakit. Penelitian ini dilakukan pada sampel bawang putih, rimpang kunyit, cabai, dan kemiri yang ditanam pada media (potato dextrose agar) serta diinkubasi selama tujuh hari. Pengamatan jamur yang tumbuh pada masing-masing sampel dilakukan secara makroskopis dan mikroskopis. Pengamatan makroskopis dengan mengamati warna pada koloni dan warna balik koloni sedangkan secara mikroskopik yang diamati berupa morfologi jamur dan jenis hifa menggunakan mikroskop dengan perbesaran $10 \times 40$. Hasil pengamatan yang didapat pada sampel bawang putih, rimpang kunyit, dan kemiri ditumbuhi jamur Aspergillus niger. Jamur pada sampel cabai yaitu Rhizopus stolonifera. Berdasarkan hasil pengamatan disimpulkan bahwa dua jenis jamur secara mikroskopis yang ditemukan, memiliki karakteristik yang berbeda baik secara makroskopis dan mikroskopis.
\end{abstract}

Kata kunci: Aspergillus niger, jamur, pengamatan makroskopis dan mikroskopis, Rhizopus stolonifera.

\begin{abstract}
Fungi are eukaryotic organisms that have spores, nucleated, not chlorophyll, and are threadlike with cell walls composed of cellulose and chitin. Fungi are heterotrophic microorganisms that are saprophytic or parasitic. Fungi have a spherical or filamentous cell structured called hyphae. Hyphae are divided into two, which are fertile hyphae that forming reproductive cells and growing upward air hyphae and vegetative hyphae, name hyphae that seek food into the substrate. In some conditions, the nature of fungi can turn into pathogens and cause various diseases. Some fungi that contaminate herbs can to produce toxins or poisons that can cause disease. This research was conducted on samples of garlic, turmeric, chilies, and candlenut which were planted on medium (potato dextrose agar) and incubated for seven days. Observation of fungi growing in each sample was carried out macroscopically and microscopically. Macroscopic observations were made with colony color adjustment and colony reverses color, while microscopically observed were fungi morphology and hyphae type using a microscope with a magnification of $10 x 40$. The results obtained in samples of garlic, turmeric, and candlenut were overgrown with Aspergillus niger. The fungus in the chili sample was Rhizopus stolonifera. Based on the results of microscopic observations that two types of fungi that were found physically, have different characteristics both macroscopically and microscopically.
\end{abstract}

Keywords: Aspergillus niger, fungi, macroscopic and microscopic observations, Rhizopus stolonifer

\section{PENDAHULUAN}

Jamur merupakan organisme eukariotik yang mempunyai spora, berinti, tidak berklorofi, dan berbentuk seperti benang dengan dinding sel yang tersusun atas selulosa dan kitin (Pawar dan Nasreen, 2016). Jamur merupakan mikroorganisme heterotrof yang bersifat saprofit atau parasit (Darwis et al., 2011). Heterotrof adalah mahkluk hidup yang tidak dapat 
membuat makanan mereka sendiri seperti tumbuhan dan ganggang. Jamur menyerap nutrisi dari lingkungan di luar tubuhnya. Beberapa jamur melakukan hal tersebut dengan mensekresikan enzim hidrolitik ke lingkungan sekelilingnya. Mekanisme kerja enzim tersebut memecah molekul kompleks menjadi senyawa organik yang lebih kecil sehingga mudah diserap oleh jamur (Campbell et al.,2011).

Jamur digolongkan menjadi 5 divisi yaitu Ascomycota, Basidiomycota, Critidiomycita, Zygomycota dan Deuteromycota. Jamur biasanya hidup pada tempat yang lembab, basah, pada sampah, sisa-sisa organisme, atau di dalam tubuh organisme lain dan dapat juga hidup di lingkungan asam. Jamur adalah salah satu organisme yang memiliki struktur sel berbentuk bola atau filamen yang disebut hifa (Pawar dan Nasreen, 2016).

Struktur pada tubuh jamur yang paling umum yakni filamen multisel dan sel tunggal atau ragi. Beberapa spesies jamur dapat tumbuh membentuk filamen dan ragi, tetapi bahkan lebih berkembang hanya sebagai filamen; relatif sedikit spesies tumbuh hanya sebagai ragi. Tubuh jamur ini biasanya membentuk jaringan filamen kecil yang disebut hifa (Sadava, 2011). Hifa merupakan suatu struktur benang - benang bercabang dan menyebar pada permukaan maupun di dalam substrat. Hifa dibedakan atas dua yaitu hifa fertile yang membentuk sel reproduktif dan pertumbuhan ke atas sebagai hifa udara serta hifa vegetatif yaitu hifa yang mencari makanan ke dalam substrat Reproduksi yang terjadi pada jamur dapat secara seksual dan aseksual dengan bentuk dan ukurannya uniseluler dan multiseluler (David, 2015).

Kondisi tertentu, sifat jamur dapat berubah menjadi patogen dan menyebabkan berbagai penyakit. Beberapa jamur yang mencemari bumbu dapur memiliki kemampuan dalam memproduksi racun atau toxin yang dapat menimbulkan penyakit (Amalia, 2013). Berbagai jenis bumbu dapur yang sudah ditumbuhi jamur umumnya akan busuk namun tidak basah (berlendir) (Hendritomo, 2010). Sehingga perlu dilakukan pemeriksaan jamur terkait dalam identifikasi dan determinasinya.

\section{METODE PENELITIAN}

Penelitian ini dilakukan di Laboratorium Mikrobiologi, Program Studi Biologi Fakultas Matematika dan Ilmu Pengetahuan Alam, Universitas Udayana. Peralatan yang digunakan dalam penelitian ini adalah lampu bunsen, pisau, cawan petri, pinset dan jarum ose. Bahan yang digunakan dalam penelitian ini adalah sampel bawang putih, cabai, rimpang kunyit, dan kemiri methylene blue, dan air steril.

Pertama disiapkan medium PDA (potato dextrose agar) yang diberi kloramfenikol dalam cawan petri. Kemudian sampel bawang putih, cabai, rimpang kunyit, dan kemiri sehat dan berjamur dipotong sepanjang $1 \mathrm{~cm}$. Sampel yang berjamur dimasukkan ke dalam cawan petri yang berisi medium PDA (potato dextrose agar) dan diberi penanda. Sampel yang sehat dibilas dengan air steril terlebih dahulu, kemudian dimasukkan ke dalam cawan petri yang berisi medium PDA (potato dextrose agar) dan diberi penanda. Sampel diinkubasi selama tujuh hari. Hifa jamur 
yang tumbuh setelah inkubasi diambil dengan jarum ose. Sampel hifa jamur yang telah diambil, diletakkan pada kaca objek dan ditetesi methylene blue kemudian tutup menggunakan kaca penutup. Diamati sampel dibawah mikroskop dengan perbesaran $10 \times 40$ kemudian catat hasil pengamatan mikroskopis.

\section{HASIL DAN PEMBAHASAN}

Berikut merupakan tabel hasil pengamatan identifikasi jamur pada masing-masing sampel uji.

Tabel 1. Hasil Pengamatan identifikasi jamur.

\begin{tabular}{|c|c|c|c|}
\hline No & Sampel & Jenis Jamur & Gambar Mikroskopis \\
\hline 1. & $\begin{array}{l}\text { Bawang putih } \\
\text { (Allium sativum) }\end{array}$ & Aspergillus niger & $\begin{array}{l}\text { Keterangan : } \\
\text { (a) Konidiospora; (b) } \\
\text { vesikel; (c) konidia. }\end{array}$ \\
\hline 2. & $\begin{array}{l}\text { Rimpang kunyit } \\
\text { (Curcuma domestica) }\end{array}$ & Aspergillus niger & $\begin{array}{l}\text { Keterangan: } \\
\text { (a) Konidiospora; (b) } \\
\text { vesikel; (c) konidia. }\end{array}$ \\
\hline 3. & $\begin{array}{l}\text { Cabai (Capsicum } \\
\text { frutescens) }\end{array}$ & Rhizopus stolonifer & $\begin{array}{l}\text { Keterangan: } \\
\begin{array}{ll}\text { (a) Sporangium; } & \text { (b) } \\
\text { sporangiofor; } & \text { (c) } \\
\text { rhizoid; } & \end{array}\end{array}$ \\
\hline 4. & $\begin{array}{l}\text { Kemiri (Aleurites } \\
\text { moluccanus) }\end{array}$ & Aspergillus niger & $\begin{array}{l}\text { Keterangan: } \\
\begin{array}{ll}\text { (a) Konidia; } \quad(b) \\
\text { vesikel; } \\
\text { konidiospora (d) hifa. }\end{array}\end{array}$ \\
\hline
\end{tabular}

Penelitian ini dilakukan secara makroskopis dan mikroskopis terhadap empat sampel yang berbeda yaitu sampel bawang putih, rimpang kunyit, cabai, dan kemiri serta digunakan PDA (potato dextrose agar) sebagai media tanam. Potato Dextrose Agar adalah media kultur yang memiliki formulasi yang sederhana sehingga paling sering digunakan dan kemampuannya untuk mendukung 
pertumbuhan miselium dari jamur. Penambahan kloramfenikol pada media potato dextrose agar bertujuan untuk menekan pertumbuhan bakteri endofit dan bakteri patogen yang kemungkinan ikut tumbuh saat isolasi (Albert et al., 2012). Pengamatan secara makroskopik dilakukan dengan mengamati warna pada koloni, warna balik koloni dan garis radial sedangkan secara mikroskopik yang diamati adalah morfologi jamur dan jenis hifa sehingga dapat teridentifikasi jenis jamur. Warna koloni dari setiap spesies bervariasi sesuai dengan warna pada sel, konidia atau sporanya (Noverita, 2009). Pengamatan di bawah mikroskop dilakukan dengan menggunakan methylen blue yang berfungsi untuk memperjelas bagian-bagian jamur dibawah mikroskop dengan mewarnai kitin pada dinding sel jamur (Haw et al., 2013).

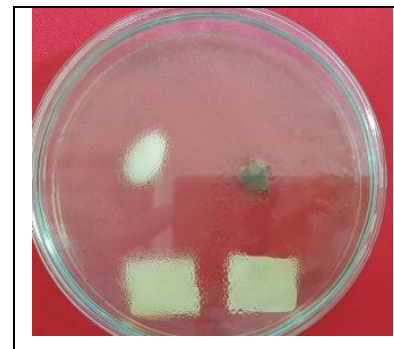

(a) sebelum diinkubasi

Gambar 1. Sampel Bawang Putih

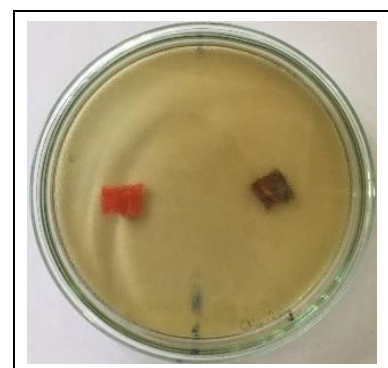

(a) sebelum diinkubasi
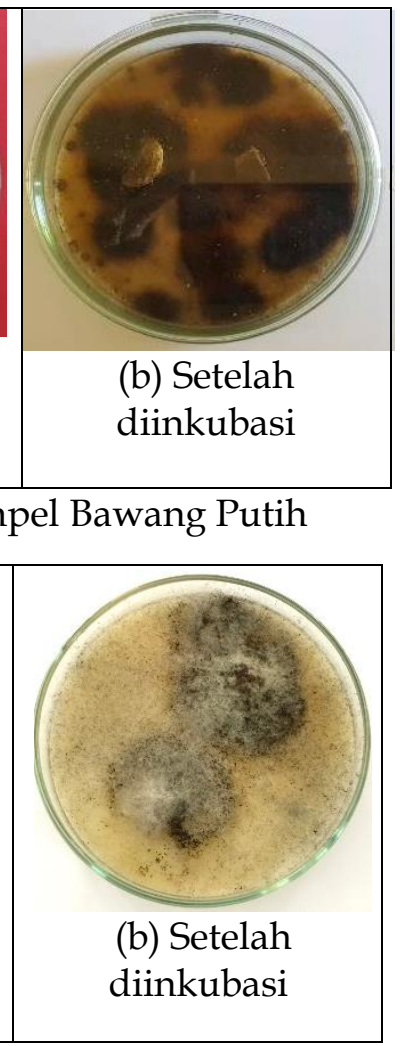

Gambar 2. Sampel Cabai
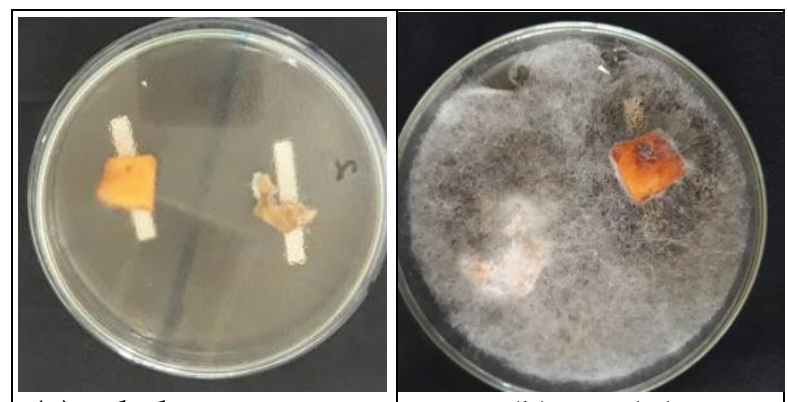

(a) sebelum diinkubasi

(b) Setelah diinkubasi

Gambar 3. Sampel Rimpang Kunyit

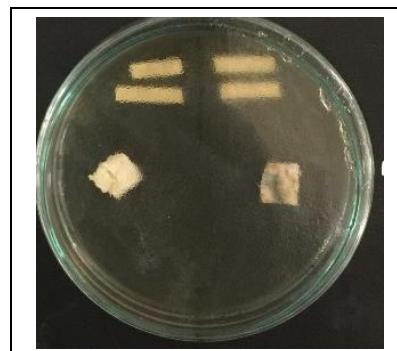

(a) sebelum diinkubasi

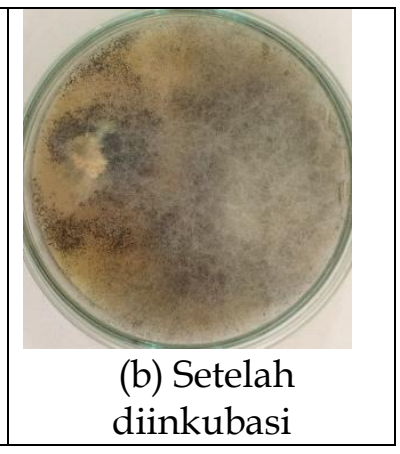

diinkubasi
Gambar 4. Sampel Kemiri

Berdasarkan hasil pengamatan, jamur yang tumbuh pada sampel bawang putih yaitu Aspergillus niger. Secara makroskopis, koloni jamur tersebut berwarna hitam dan warna balik koloni berwarna kehitaman karena dipenuhi spora. (Irma, 2015). Pengamatan secara mikroskopis menunjukan Aspergillus niger karena jenis jamur yang teramati berfilamen, memiliki konidia, hifanya bersepta dengan miseliumnya bercabang, konidiofornya bersepta, dan memiliki vesikel (Irma, 2015). Aspergillus niger secara umum ditemukan tumbuh berupa saprofit pada kompos, daun mati, dan vegetasi yang membusuk lainnya. Sporanya tersebar luas serta sering dikaitkan dengan tanah dan bahan organik (Wulandari dkk, 2016).

Sampel rimpang kunyit dan kemiri juga ditumbuhi jamur Aspergillus niger yang memiliki bentuk dan karakteristik yang sama. Karakteristik jamur Aspergillus niger dapat tumbuh dengan suhu optimum 
$35^{\circ} \mathrm{C}-37^{\circ} \mathrm{C}$, bersifat aerobic atau memerlukan oksigen yang cukup (Abed et al., 2017). Aspergillus niger juga toleran terhadap aktivitas air yang rendah, kelembaban relatif rendah dan mampu tumbuh pada substrat dengan potensial osmotis cukup tinggi, sehingga pada ketiga tumbuhan dapat tumbuh jamur tersebut karena nutrisi yang memadai untuk tumbuhnya jamur (Ibrahim et al., 2014). Adanya jamur Aspergillus niger pada manusia akan menyebabkan gejala sakit perut, muntah, kejang bahkan kematian karena senyawa aflatoksin yang dihasilkan (Edyansyah, 2013).

Hasil pengamatan menunjukkan bahwa jamur yang tumbuh pada sampel cabai (Capsicum frutescens) adalah Rhizopus stolonifer dengan warna koloni putih pada spora muda dan warna koloni hitam pada spora tua. Warna putih pada koloni Rhizopus stolonifer disebabkan karena terbentuknya padatan kompak berupa benang halus akibat adanya miselia jamur yang tumbuh (Dewi dan Aziz, 2011). Hal ini sesuai dengan ciri lain dari koloni tersebut yaitu koloni tidak beraturan, permukaan berkapas, hifa tidak bersekat, sporangiofor tidak bersekat dan sporangium berbentuk bulat agak lonjong (Sastrahidayat, 2014). Jamur Rhizopus stolonifer dapat merusak bahan organik melalui dekomposisi secara cepat. Sporanya mudah berterbangan dan bisa terdapat di udara serta pertumbuhan cepat pada suhu $20-30^{\circ} \mathrm{C}$ (Smith, 2007). Secara mikroskopis mempunyai hifa pendek bercabang-cabang, sporangiofor, miselium yang sering tumbuh membentuk rhizoid. Sporangium pada hifa mendukungnya terpisah oleh satu sekat, yang menonjol ke dalam sporangium. Tonjolon ini disebut kolumela (Natawijaya dkk., 2015).

\section{KESIMPULAN}

Pemeriksaan jamur bertujuan untuk mengetahui jenis jamur yang menginfeksi sampel dan karakteristik jamur secara makroskopik dan mikroskopik. Berdasarkan hasil pengamatan disimpulkan bahwa dua jenis jamur secara mikroskopis yang ditemukan, memiliki karakteristik yang berbeda baik secara makroskopis dan mikroskopis. Jamur yang tumbuh pada sampel bawang putih, rimpang kunyit, dan kemiri yaitu Aspergillus niger, jamur pada sampel cabai yaitu Rhizopus stolonifera. Jamur Aspergillus niger memiliki karakteristik koloni jamur berwarna hitam dan warna sebalik koloni berwarna kehitaman karena dipenuhi spora. Jamur Rhizopus stolonifera memiliki karakteristik dengan warna permukaan koloni putih dan koloni putih. Pengamatan secara mikroskopis Aspergillus niger memiliki konidia, hifanya bersepta dengan miseliumnya bercabang, konidiofornya bersepta, vesikel dan pada ujungnya terdapat sterigma. Rhizopus stolonifer mempunyai hifa pendek bercabang-cabang, sporangiofor, miselium yang sering membentuk rhizoid, dan kolumela.

\section{DAFTAR PUSTAKA}

Abed, N. E., Salem, I. B., Khedher, M.B., Hamdi, M.M., and M'Hamdi, N.B. 2017. Isolation and Identification of Fungal Communities in Organic and Conventional Soils. International Journal of Current Microbiology and Applied Sciences.Vol.6(4): 1111-1123 
Albert, S., B. Pandya and A. Pandhiar. 2012. Evaluation of Colony Characteristics and Enzymatics Activity of Some Fungi for Potential Use in Co-Culture for Bio Pulping. Asian Journal of Biological and Life Sciences 1(2): 83-89.

Amalia, N. 2013. Identifikasi Jamur Aspergillus flavus pada Kacang Tanah (Arachis hypogaea L.) yang Dijual di Pasar Kodim. Jurnal Analisis Kesehatan Klinikal Sains 1(1): 1-10.

Campbell, N.A. dan Reece, J. B. 2011. Campbell Biology. Tenth Edition. Boston: Benjamin Cummings/Pearson. Darwis, W., A. R. Mantovani, Rochmah Supriyati. 2011. Determinasi Jamur Lycoperdales yang Terdapat di Desa Pajar Bulan Kecamatan Semidang Alas Kabupaten Seluma Bengkulu. Jurnal Ilmiah Konservasi Hayati 7(1): 6-10.

David S. Hibbett. 2015. Comparative Genomics of Early-Diverging Mushroom-Forming Fungi Provides Insights Into The Origins of Lignocellulose Decay Capabilities. Journal Oxford Mol Biol Evol 3(3): 28-42.

Desy V. P., Gede R., Sri I. 2014. Identifikasi Aspergillus flavus Pada Biji Kacang Tanah Busuk Atau Keriput Yang Dijual. Jurnal Klinika Laboratory 2(1): 45-62.

Dewi, R. S. dan S. Aziz. 2011. Isolasi Rhizopus oligosporus pada Beberapa Inokulum Tempe di Kabupaten Banyumas. Molekul. 6(2): 93-104.

Edyansyah, E. 2013. Keberadaan Jamur Kontaminan Penyebab Mikotoksikosis pada Selai Kacang yang Dijual Di Pasar Tradisional Kota Palembang Tahun 2013. Jurnal Agrisains. 4(7): 1723
Haw, B. P., I. Asma, O. Eugene, S. Sasidharan. 2013. Phenotyping Identification of Candida albicans for the Production of In House Helicase for Nucleic Acid-Based Detections for Fast Diagnosis. Research Journal of Pharmaceutical, Biological and Chemical Sciences. 4(2):576-583.

Hendritomo, H. I. 2010. Jamur Konsumsi Berkhasiat Obat. Edisi I. Lily Publisher. Yogyakarta.

Ibrahim, M., Shehu, K., Sambo, S., Tukur, U., Umar, I. A., dan Tafinta, I.Y. 2014. Identification of Fungi Associated with Storage Rots of Irish Potato (Solanum Tuberosum L.) Tubers in Sokoto Metropolis. Annals of Biological Sciences.Vol.2(2):1-4.

Ilmiyah, Z., Tri Asri, M., Evie R., dan Yunimar. 2015. Uji Antagonisme Jamur Endofit Tanaman Stroberi terhadap Alternaria alternata Jamur Penyebab Bercak Daun (Leaf Spot) pada Tanaman Stroberi Secara In Vitro. Jurnal Ilmiah Biologi 4(1): 19-24.

Irma. 2015. Optimasi Media Pertumbuhan Aspergillus Niger Dengan Menggunakan Tepung Singkong. Jurnal Ilmiah Universitas Islam Negeri Allaudin 1(1): 234-245.

Irdawati, D. Handayani dan V. Erda. 2013. Cendawan Kontaminan Kontaminan Pada Beberapa Jenis Sayuran Di Pasar Raya Padang. Jurnal Eksakta. 1 (14) : $116-124$.

Natawijaya, D., Adam S., dan Dwi Pangesti. 2015. Uji Kecepatan Pertumbuhan Jamur Rhizopus stolonifer dan Aspergillus niger yang Diinokulasikan pada Beberapa Jenis Buah Lokal. Jurnal Siliwangi 1(1): 32-40. 
Noverita. 2009. Identifikasi Kapang dan Khamir Penyebab Penyakit Pada Manusia Pada Sumber Air Minum Penduduk Sungai Ciliwung dan Sumber Air Sekitarnya. Jurnal Ilmiah Penelitian 2(2):12-22.

Pawar, S. and S. Nasreen. 2016. Isolation and Identification of Some Pathogenic Fungi from Different Infected Vegetables. International Journal of Innovative Research in Science, Engineering and Technology 5(3):245255.

Sadava, D.E. 2011. Life : the science of biology. Gordonsville : W.H. Freeman $\&$ Co.

Sastrahidayat, I. R. 2014. Penyakit Tanaman Buah-Buahan. UB Press. Malang.
Smith, S. N. 2007. An Overview of Ecologicl and Habitat Aspects in The Genus Fusarium with Special Emphasis on The Soil-borne Pathogenic Form. Plant Pathol Journal Biology. 2(7): 97-120.

Wulandari, D. E., Asrul, dan Irwan L.. 2016. Seleksi Jamur Antagonis Aspergillus niger Dari Beberapa Lahan Perkebunan Kakao Untuk Mengendalikan Phytophthora palmivora. Jurnal Agroland. Vol.23(3):233-242 